International Journal of Instruction e-ISSN: 1308-1470 • www.e-iji.net

Article submission code: 20200727144334

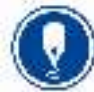

Received: $27 / 07 / 2020$ Revision: 05/02/202
July $2021 \bullet$ Vol.14, No.3

p-ISSN: 1694-609X

pp. $945-964$

Accepted: 28/02/2021

OnlineFirst: 23/06/2021

\title{
Learning Motivation as Intervening in the Influence of Social Support and Self Regulated Learning on Learning Outcome
}

\section{Mohammad Muchlis Solichin}

Institut Agama Islam Negeri Madura, Indonesia, muchlissolichin.@iainmadura.ac.id

\section{Achmad Muhlis}

Institut Agama Islam Negeri Madura, Indonesia, achmad.muhlis@iainmadura.ac.id

$\begin{array}{llll}\text { Ahmad Ghufran Ferdiant } & & & \\ \text { Institut Agama Islam Negeri } & \text { Madura, }\end{array}$

Institut Agama Islam Negeri Madura, Indonesia,

ahmadghufranferdiant@iainmadura.ac.id

The aim of this study is to examine the effect of social support and self-regulated learning on the learning outcomes in Islamic Education courses in the Management of Islamic Education, Faculty of Tarbiyah State Islamic State Institute for Islamic Studies of Madura. To achieve the purpose, the researcher used quantitative research method. The Participat in this study were 143 students students of Islamic Education Management Departement. This study draws samples using the probability sampling method with simple random sampling type, the sample is 105 students. Research Instrument used is questionnaire. The analysis of data in this study uses SPSS Version 24. From the research conducted, conclusions can be drawn as follows: 1) There is a simultaneous influence of social support and selfregulated learning on learning motivation, they are about $8.8 \%$. This means that there are still $91.2 \%$ influenced by other variables. 2) There is a simultaneous influence of social support, self-regulated learning, and learning motivation on the learning outcomes of $6.5 \%$ which means that there are still $93.5 \%$ which is influenced by other variables.

Keywords: social support, self-regulated learning, learning motivation, learning outcome, student

\section{INTRODUCTION}

Education is an effort to equip students to be able to have the abilities, attitudes, and skills needed when they live their lives. To have these abilities, educators are expected to be able to empower the potential of intelligence, emotional attitudes, and skillsthrough the learning process.Ideally, effective learning positions students as learning subjects. Placement of students as subjects of learning is an embodiment of student-centered learning paradigms. In this type of learning, the teacher makes an effort 
so that students show active involvement, by allowing students to be able to physically, mentally and actively construct understanding, experience, and attitudes and skills to achieve optimal learning and learning outcomes.

Viewed from the aspect of students, the learning outcomes are seen as a change and development of understanding, attitudes, and skills that are better when compared to the conditions before learning. Thus, it can be stressed that learning outcomes are the result of changes in all learning activities and will be constantly inherent in students and become part of their lives. Improved learning outcomes can be done by strengthening learning motivation of students.

A student who has the motivation to excel will foster a strong and permanent awareness within himself. Here, motivation becomes the motivator/driving force in achieving the highest achievements eventhough he faces challenges and obstacles that are not easy to get through. Achievement motivation is the willingness/desire of a student to make an effort to achieve success/learning achievement.

Meanwhile, in strengthening learning motivation, the role of parents is very dominant. Parents were the first educators to instill the importance of education for their children. Equally important in growing motivation is the support of peers at school. Friends play a role in assisting the task completion, providing stationery and book loans, places to complain, discuss, and exchange opinions in completing tasks.

Further, motivation to learn is also determined by the ability of students to organize themselves in learning. Self-regulated learning is an effort to supervise, control, monitor, and evaluate abilities, strengths, attitudes, and behaviors in the learning process. These abilities are closely related to learning motivation. Self-regulated learning is seen as an active student activity to achieve learning goals by making efforts to plan, arrange, organize, manage, monitor, supervise, and evaluate the implemented learning process.

Research objectives to prove and analyze: 1)The influence of social support and selfregulated learning on learning motivation both partially and simultaneously. 2) The influence of social support, self-regulated learning, and learning motivation on learning outcomes both partially and simultaneously 3 ) The influence of social support and selfregulated learning on learning outcomes through learning motivation

\section{Social Support}

In various studies mentioned that social support provides a positive impact for an individual in everyday life. Social support can provide positive construction, such as providing a sense of optimism in influencing his future, increasing security, comfort and mental health. (Wang et.all, 2014: 41; Kim, 2014) Likewise, social support can reduce negative impacts, such as stress, tension, difficulties and obstacles faced in life. (Alsubaie et.all., 9; Hether, et.al. 2014; Schneider, et al., 2005)

Social support can function as a social bond that provides an overview of the level of relationships between individuals (interpersonal). the relationship produces friendship, kinship, cooperation that gives psychological satisfaction to someone. (Umayyah, 2018, 32-41)Social support can be in the form of assistance and attention received by someone 
from immediate family members (father, mother, and sister). parents can meet the learning needs (Smet, 1994.) provide support in the form of planting values and beliefs in learning, which is the capital to obtain learning success. (Barbosa, et.all. 2015).

Social support can be interpreted as support which includes six things, namely: integration, freedom in providing assistance, closeness / attachment, appreciation and positive recognition, dependency between individuals, and guidance, direction and information when a person faces various problems and difficulties in life. (Coutts, et.all., 2005: 200),

There are four aspects of social support, namely: (1) Emotional support, which is in the form of expressions of caring, attention, sympathy, empathy from someone to the person who is given support and assistance so that the person feels emotional touch avoiding alienation. 2) Appreciation support, namely support that gives expression of approval and giving positive value to ideas, ideas, thoughts, feelings, attitudes and actions of a person, 3) instrumental support is a support in the form of direct assistance in completing tasks or in the form of material assistance and financially in carrying out the tasks and the learning process. 4) Information support, which is support in the form of guidance, guidance, advice, input, one's direction to others in implementing the learning process and overcoming the problems faced (Marhamah \& Hamzah, 2016, 151; Ati, et.all. 2018)

\section{Self-Regulated Learning}

Self-regulated learning (SRL) is the ability of an individual in managing / controlling and controlling himself to be able to format and create conditions / situations of learning that are effective, creative in order to achieve the desired learning goals. SRL students have the ability and skills in managing and managing their own time, methods, and learning methods in order to be able to direct themselves towards the stated learning goals. Thus, SRL can have an influence on the learning outcomes obtained. (Banarjee \& Kumar, 2014),

Students who have the ability to use self regulated learning, he can have an awareness of the importance of learning outcomes, and can do planning in determining ways and methods of SRL activities to get the expected learning outcomes. (Jafarigohar \& Mortazavi, 2013; Johnson \& Davie, 2014) In general students who have the ability / motivation in organizing themselves in learning show high learning outcomes. Setiani, et.all., 2018: 17; Zimmerman, 1989.

SRL can be implemented in several activity phases, namely as follows: 1) the design phase in learning which consists of the activities of analyzing the task, setting learning objectives, design methods / learning strategies, 2) the monitoring phase is phase aimed at re-examining whether the activities carried out in accordance with the objectives to be achieved, 3) self-evaluation phase, namely activities to assess, review whether the learning outcomes achieved are in line with expectations? 4) reflection phase, is an activity to reflect on the learning activities (Saks \&, Leijen, 2014; Montalvo \& Torres, 2004: 5-7; Eissa, 2015). 
With good SRL, students tend to diligently complete their tasks and maintain a high level of effort in completing their assignments even though they have to face various challenges and obstacles in their assignments. (Harding et.all. 2019; Abadikhah, et.all., 2018; Paris \& Paris, 20033 Meanwhile, students with poor self-regulated learning have a view that they unable to exercise good control over their behavior (Marlina, 2017: 72; Cetin, 2015.) Also, he views tasks as well as views himself unable to control his behavior well. Individuals see tasks as burdensome burdens and cannot be controlled by themselves and tend to delay the completion of these tasks (procrastination). (Ilyas, 2016; Al Mutawaha et.all., 2017; Pintrich \& De Groot, 1990)

\section{Learning Motivation}

Motivation is defined as a state of self that moves a person to carry out certain activities to achieve the desired goal. Motivation as seen as encouragement, pressure, driving force, will power, desire, enthusiasm to achieve desired goals. (Pintrich, 2003) Motivation is also defined as a state of self that gives rise to desires, desires, desires, which are directed to achieve certain goals. (Ali et.all. 2010; 2019; Tambunan \& Siregar, 2016; Lahijan, 2016)

Learning motivation (LM) is a condition that gives rise to enthusiasm, sincerity, and sustainability in carrying out certain activities to achieve certain goals. There are characteristics of a person who has LM, namely, 1) persevering, serious, serious, persistent in carrying out learning activities, 2) showing independence in carrying out tasks, and 3) happy to get challenges and get bored quickly with routine tasks. LM is the power of movement and impulse from outside and within students which are marked by the occurrence of changes in energy to be able to carry out learning activities to achieve the desired learning goals. (Anwari, 2019; Bakar, 2014)

The dominant role of LM in increasing student learning activities, which consequently can carry out learning activities seriously, diligently to achieve learning goals, namely obtaining academic achievement. (Steinmayr et al., 2019; Kariadinata, et al., 2019 Some of the efforts of teachers in motivating to learn for their students are as follows: compiling and giving an explanation of the learning objectives at the beginning of learning, giving praise, prizes, and smiles, (Murayama, 2018) giving scores (grades) appropriate and by the efforts of students, instill the importance of learning, compiling and carrying out repetition, correcting and improving assignments given to students, fostering healthy competition between students, punishing in an educative way and by the level of difficulty of students. With the motivation of a student to achieve optimal learning outcomes that he gets recognition and acceptance from parents, siblings, communities, teachers, and friends. (Leonangung, 2018)

Several factors influence student LM, namely: 1) aspirations/desires/ideas in learning that can produce the will/desire/will to be able to achieve the learning objectives. (Prihantoro, et. All., 2018) 3) the mental and physical state of students in learning. 4) the learning environment is crucial to the growth of motivation to learn, both the physical environment such as classroom conditions and cleanliness, cleanliness of the school environment, library conditions, the completeness of reference books, break rooms, and 
non-physical environments such as the competence of teachers, peers, parents, siblings, and surrounding communities. (Thohir, 2017; Ahmed, 2015).

LM can be divided into two parts, namely 1) intrinsic motivation is the encouragement that comes from students, in the form of desire, will, willingness, an awareness that gives rise to learning activities. 2) extrinsic motivation, namely encouragement from outside students in the form of teacher teaching abilities, completeness of reference books, attention, and support of parents and peers and others. (Pan, 2010; Saeed \& Zyngier, 2012)

\section{Learning Outcomes}

Learning outcomes (LO) are defined as the level of success obtained by students based on cognitive, affective, and psychomotor changes.. These changes are produced through evaluations in the form of tests which are usually illustrated with certain numbers. LO changes in the understanding/knowledge, attitudes, and skills of a student as a result of learning activities. Students individually or in groups expect success in their learning activities (Irawan, et.all., 2019)

LO are formulated as cognitive, affective, and psychomotor domains, each of which includes learning objectives related to knowledge, understanding, and intellectual ability development. The affective domain includes learning objectives that describe changes in attitudes, values, responses, and acceptance. Meanwhile, the psychomotor domain includes learning outcomes related to skills. (Saputra, 2019; O'Neill, 2005; Prøitz, 2010)

Specifically, cognitive LO are changes in intellectual abilities which include the level of knowledge and understanding called low-level abilities, then LO at high levels in the form of application, analysis, synthesis, and evaluation. (Salleh, 2017; Adams, 2015 ; Shi, et.all. 2020; Miharja 2019)

\section{METHOD}

\section{Research Design}

According to the type of data, this research is a quantitative research method. This research is explanatory research that aims to explain the position of the variables studied and the relationship or influence between the independent variables, namely social support variables $\left(\mathrm{X}_{1}\right)$ and SRL $\left(\mathrm{X}_{2}\right)$; intervening variable here is the LM variable $(\mathrm{Y})$; and the dependent variable, namely LO $(\mathrm{Z})$. And correlational research, which tries to see whether two or more variables have relationship or not and how big the relationship is and how the direction of the relationship goes (Syofian, 2015: 7).

Research Thought Framework 


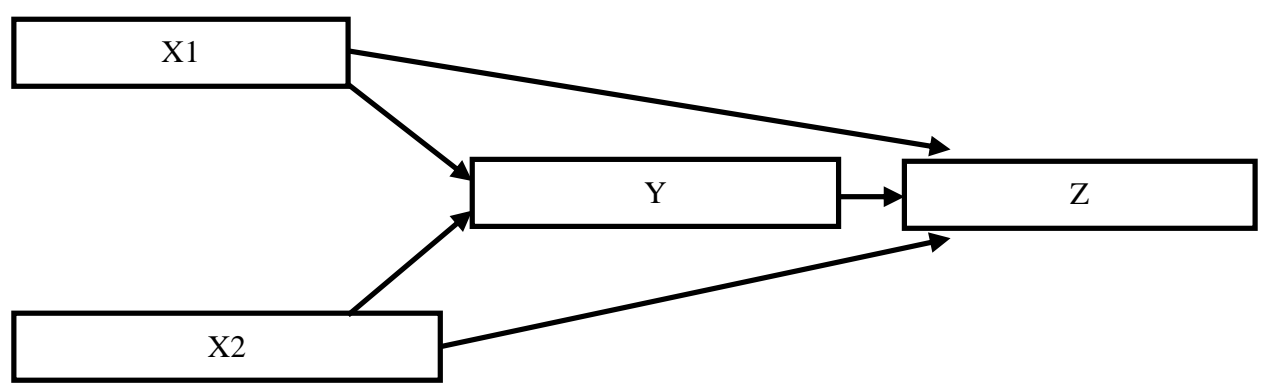

Figure 1

Research thought framework

\section{Research Hypothesis}

1. H1: There is a significant the direct effect of social support $\left(\mathrm{X}_{1}\right)$ on Learning Motivation (Y)

2. H2: There is a significant The direct influence of self-regulated learning, $\left(\mathrm{X}_{2}\right)$ on Learning Motivation ( $\mathrm{Y}$ )

3. H3: There is a significant the simultaneous influence of social support (X1) and SRL (X2) on Learning Motivation (Y)

4. H4: There is a significant the direct influence of social support (X1) on learning outcomes (Z)

5. H5: There is a significant the direct influence of SRL (X2) on the LO learning outcomes (Z)

6. H6: There is a significant the direct influence of learning motivation on learning outcome.

7. H7: There is a significant the simultaneous influence of social support (X1), selfregulated learning, and learning motivation on learning outcomes.

8. H8: There is a significant a significant the indirect influence of social support (X1) on learning outcomes through learning motivation variables.

9. There is indirect influence of the self-regulated learning variable (X2) on learning outcomes $(\mathrm{Z})$ through learning motivation variables $(\mathrm{Y})$.

\section{Participant}

The Participant in this study were students of Islamic Education Management Study Program $4^{\text {th }}$ semester of A, B, C, and D classes, totaling 143 students. This study draws samples using the probability sampling method with simple random sampling technique, where the technique used to determine the number of samples uses the Solvin Technique $\mathrm{n}=\mathrm{N} /(1+\llbracket \mathrm{Ne} \rrbracket \wedge 2)$ where $\mathrm{n}$ is the number of samples, $\mathrm{N}$ is the number population, and $\mathrm{e}$ is the estimated error rate $(=5 \%)$ so that the sample size is 105 students. 


\section{Research Instruments}

Measurement of independent variables, intervening variable, and dependent variablein the questionnaire using a Likert scale with a rating scale (score), from 1 (strongly disagree) to 5( strongly agree). While the dependent variable is the learning outcome variable using the Achievement Index value (IP).

The instrument validity test in this study used the Pearson Product Moment Validity Test with SPSS Version 24. The basis of the decision making, if the significance value is less than 0.05 , then the instrument used is considered valid. While the reliability test of the instrument used in this study uses the Cronbach Alpha Technique with SPSS Version 24. The basis for decision making, if the Cronbach Alpha value is greater than 0.6 , the research instrument used is considered reliable (Sujarweni, 2014).

\section{a. Social Support Variable $\left(\mathrm{X}_{1}\right)$}

The instrument validity test of this social support variable goes through 2 stages of testing. In the first stage indicators of the social support variable consisted of 21 question items so that there were 18 questions in the second testing phase. Based on the results of the instrument validity test of 18 questions known to the value of sig. (2tailed). Because the significance value is less than 0.05 , it can be concluded that 18 questions from the social support variable is considered valid, while the instrument reliability test results for social support variables are 0,902. Because the Cronbach's Alpha value of $0.902>0.6$, it can be concluded that the research instrument is declared reliable.

b. SRL variable $\left(\mathrm{X}_{2}\right)$

The instrument validity test of this SRL variable goes through 2 stages of testing. In the first stage the indicators of the self-regulated learning variable consist of 25 questions so that it becomes 21 questions at the last testing stage. Because the significance value is smaller than 0.05 , it can be concluded that 21 questions from the SRL variable are considered valid. While the instrument reliability test results for the self-regulated learning variable are 0,704. Because the Cronbach's Alpha value is $0.704>0.6$, it is concludes that the research instrument is declared reliable.

c. LM variable (Y)

The instrument Validity Test of this LM variable goes through 3 stages of testing. In the first stage the indicator of the self-efficacy variable consists of 25 question items so that it becomes 21 questions at the last testing stage. Because the significance value is lower than 0.05 , it can be concluded that 21 items of LM variables are considered valid. While the instrument reliability test results for LM variables are 0,754. Because the Cronbach's Alpha value is 0.754> 0.6, it is concludes that the research instrument is declared reliable.

\section{Data Analysis}

Test-Path Analysis Prerequisites

Path analysis prerequisite test in this study used SPPS Version 24. The analysis prerequisite test used included: 


\section{a. Data Normality Test}

The data normality test used in this research is the Kolmogorov Smirnov normality test. Kolmogorov Smirnov normality test is part of the classic assumption test that aims to determine whether the residual value is normally distributed or not on the basis of decision making if the value of Asymp. Sig. (2-tailed)> 0.05, then the residual value is considered to be normally distributed. The results of data normality in this study can be seen in the table below.

Table 1

Data normality test

One-Sample Kolmogorov-Smirnov Test $\quad$ Standardized Residual

$\mathrm{N}$

\begin{tabular}{lll}
\hline Normal Parametersa,b & Mean &, 0000000 \\
\cline { 2 - 3 } & Std. Deviation &, 98547138 \\
\hline Most Extreme Differences & Absolute &, 089 \\
\cline { 2 - 3 } & Positive &, 070 \\
\cline { 2 - 3 } Negative &,- 089 \\
\hline Test Statistic &, 089 \\
\hline Asymp. Sig. (2-tailed) &, $038 \mathrm{c}$ \\
\hline a. Test distribution is Normal. & \\
\hline b. Calculated from data. & \\
\hline c. Lilliefors Significance Correction.
\end{tabular}

Based on the output above it is known that the Asymp.Sig value. (2-tailed) of 0.038> 0.05 , it can be concluded that the residual value is not normally distributed.

\section{b. Multicollinearity Test}

Multicollinearity test aims to test whether the dependent variable correlates or not, a good regression model that is, if there is no correlation between the dependent variables. If the regression results have a VIF value of $\leq 10.00$, it can be concluded that there is no multicollinearity in the regression model (Ghozali, 2011). Multicollinearity test results can be seen in the table below.

Table 2

Coefficients

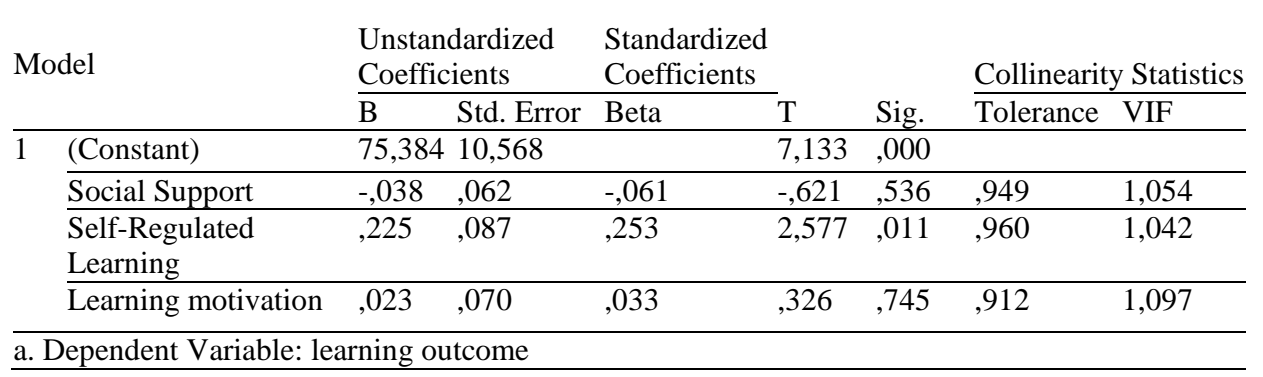


Based on the coefficients table above, it is known that the VIF value of social support is 1.054, SRL (1.042), and LM (1.097), because the VIF value $\leq 10.00$, it can be concluded that this multiple regression model does not occur symptoms multicollinearity.

\section{c. Linearity Test.}

Table 3

ANOVA table

\begin{tabular}{|c|c|c|c|c|c|c|c|}
\hline & & & Sum of Squares & df & Mean Square & $\mathrm{F}$ & Sig. \\
\hline \multirow{5}{*}{$\begin{array}{l}\text { Learning Outcome } \\
* \text { Social Suppor }\end{array}$} & \multirow{3}{*}{$\begin{array}{l}\text { Between } \\
\text { Groups }\end{array}$} & (Combined) & 329,492 & 22 & 14,977 & ,915 & ,577 \\
\hline & & Linearity & 5,669 & 1 & 5,669 & ,346 & ,558 \\
\hline & & $\begin{array}{l}\text { Deviation fro } \\
\text { Linearity }\end{array}$ & 323,823 & 21 & 15,420 & ,942 & ,541 \\
\hline & \multicolumn{2}{|c|}{ Within Groups } & 1342,565 & 82 & 16,373 & & \\
\hline & \multicolumn{2}{|c|}{ Total } & 1672,057 & 104 & & & \\
\hline
\end{tabular}

Based on the ANOVA table above, it is known that the value of sig. Deviation from linearity of $0.541>0.05$, it can be concluded that there is a linear relationship between the LO variable and the social support variable.

Table 4

ANOVA table

\begin{tabular}{|c|c|c|c|c|c|c|c|}
\hline & & & Sum of Squares & df & Mean Square & $\mathrm{F}$ & Sig. \\
\hline \multirow{5}{*}{$\begin{array}{l}\text { Learning Outcome } \\
\text { Self-Regulated } \\
\text { Learning }\end{array}$} & \multirow{3}{*}{$\begin{array}{l}\text { *Between } \\
\text { Groups }\end{array}$} & (Combined) & 287,168 & 18 & 15,954 & ,991 & ,478 \\
\hline & & Linearity & 102,495 & 1 & 102,495 & 6,365 & 013 \\
\hline & & $\begin{array}{l}\text { Deviation } \\
\text { from } \\
\text { Linearity }\end{array}$ & 184,673 & 17 & 10,863 & ,675 & ,819 \\
\hline & \multicolumn{2}{|c|}{ Within Groups } & 1384,889 & 86 & 16,103 & & \\
\hline & \multicolumn{2}{|c|}{ Total } & 1672,057 & 104 & & & \\
\hline
\end{tabular}

Based on the ANOVA table above, it is known that the value of sig. Deviation from linearity of $0.819>0.05$, it can be concluded that there is a linear relationship between the learning outcomes variable and the SRL

Table 5

ANOVA table

\begin{tabular}{|c|c|c|c|c|c|c|c|}
\hline & & & Sum of Squares & $\mathrm{df}$ & Mean Square & $\mathrm{F}$ & Sig. \\
\hline \multirow{5}{*}{$\begin{array}{l}\text { Learning } \\
\text { Outcome } \\
\text { Learning } \\
\text { Motivation }\end{array}$} & \multirow{3}{*}{$\begin{array}{l}\text { Between } \\
\text { *Groups }\end{array}$} & (Combined) & 386,569 & 25 & 15,463 & ,950 &, 540 \\
\hline & & Linearity & 1,624 & 1 & 1,624 & , 100 & ,753 \\
\hline & & $\begin{array}{l}\text { Deviation fr } \\
\text { Linearity }\end{array}$ & $\mathrm{n} 384,945$ & 24 & 16,039 & ,986 & ,494 \\
\hline & \multicolumn{2}{|c|}{ Within Groups } & 1285,488 & 79 & 16,272 & & \\
\hline & \multicolumn{2}{|l|}{ Total } & 1672,057 & 104 & & & \\
\hline
\end{tabular}


Based on the ANOVA table above, it is known that the value of sig. Deviation from linearity of $0.494>0.05$, it is concludes that there is a linear relationship between the LO variable and $\mathrm{LM}$ variable

\section{d. Autocorrelation Test}

The autocorrelation test used in this study uses the Durbin Watson autocorrelation test with SPSS Version 24 on the basis of decision making, if the Durbin Watson value is smaller than the DL value, it can be concluded that there is no autocorrelation. The results of the autocorrelation test are shown in the table below.

Table 6

Model summary

\begin{tabular}{lllll}
\hline Model $\mathrm{R}$ & $\mathrm{R} \mathrm{Square}$ & $\frac{\text { Adjusted R Square }}{\text { Std. Error of the Estimate }}$ & $\frac{\text { Durbin-Watson }}{3,93390}$ \\
\hline 1 &, $255 \mathrm{a}$ &, 065 &, 037 & 895 \\
\hline a. Predictors: (Constant), Motivasi Belajar, Self-Regulated Learning, Dukungan Sosial
\end{tabular}

b. Dependent Variable: Learning outcome

Based on the Summary Model table above, it is known that the Durbin Watson value of $0.895<1.6237$ (see the Durbin Watsun table with the number $\mathrm{n}=105$ and the value $\propto=$ $5 \%$ ), it can be concluded that there is no autocorrelation.

\section{Hypothesis Testing}

Hypothesis testing in this study uses SPSS Version 24. Hypothesis testing used includes:

a. Multiple Regression Test

Multiple Regression Analysis is used if you want to predict how the condition (ups and downs) of the dependent variable $(\mathrm{Y})$, if two or more independent variables $(\mathrm{X})$ as a predictor factor are manipulated or increased in value (Sugiyono: 2010, 275). Multiple regression analysis aims to determine whether there is an influence of two or more independent variables $(\mathrm{X})$ on the dependent variable $(\mathrm{Y})$ or not. Multiple regression test in this study uses SPSS version 24 with decision making techniques, if the significance value is smaller than 0.05 , then there is an influence between the independent variable and the dependent variable

\section{b. Path Analysis Test}

Path analysis is used to determine the causal relationship with the aim of explaining direct effect and indirect effect of a set of variables, as a cause variable for other variables which are effect variables. The path analysis diagram models in this study are listed in the figure below: 


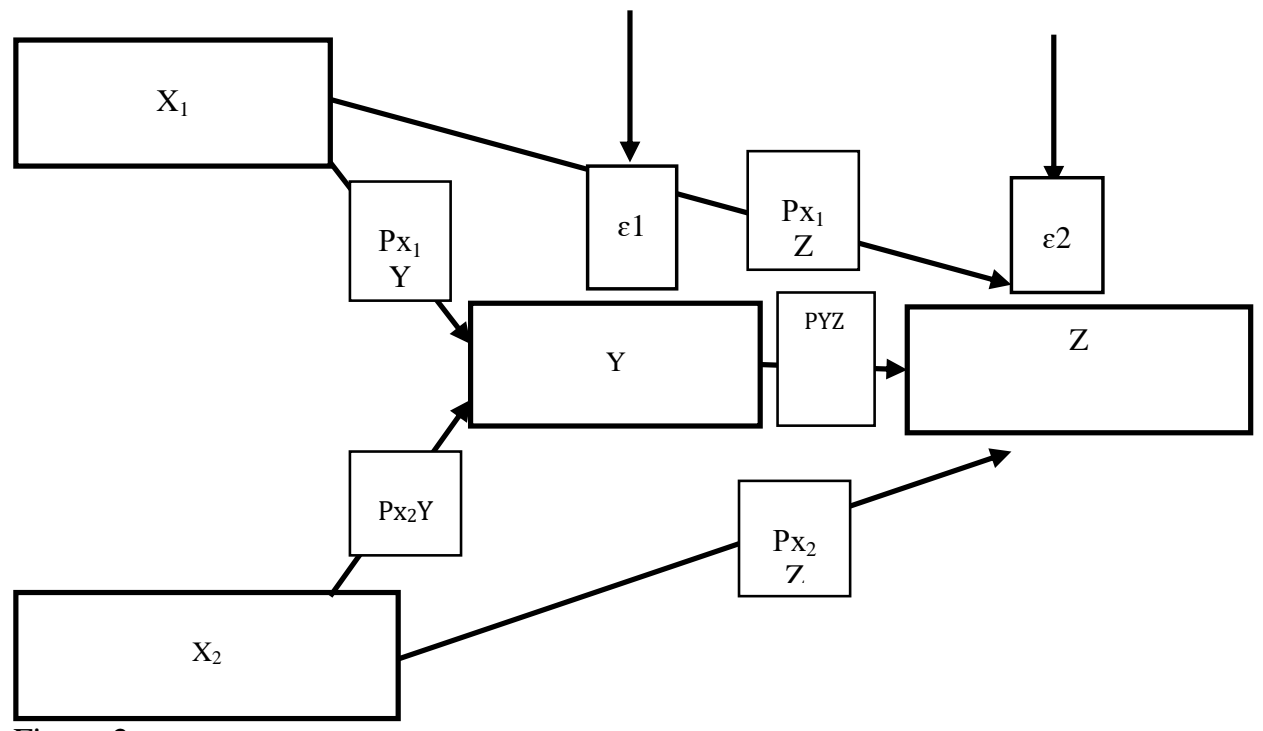

Figure 2

Path analysis diagram model

The path diagram above consists of two structural equations, where $\mathrm{X} 1$ and $\mathrm{X} 2$ are independent variables in this case called exogenous variables and $\mathrm{Y}$ and $\mathrm{Z}$ are dependent (endogenous). The structural equation can be seen as follows:

$\mathrm{Y}=\mathrm{PYX} 1+\mathrm{PYX} 2+\varepsilon 1$ Structural Model I

$\mathrm{Z}=\mathrm{PZX} 1+\mathrm{PZX} 2+\mathrm{PZY}+\varepsilon 2 \ldots .$. Structural Model II

\section{FINDINGS}

\section{Hypothesis Testing}

a. Multiple Regression Test

The multiple regression test in this study aims to determine the direct effect of the independent variable and the dependent variable both partially and simultaneously. The results of the multiple regression test can be seen in the table below.

Table 7

Coefficientsa

\begin{tabular}{|c|c|c|c|c|c|c|}
\hline \multirow[t]{2}{*}{ Model } & & \multicolumn{2}{|c|}{ Unstandardized Coefficients } & \multicolumn{2}{|c|}{$\begin{array}{l}\text { Standardized } \\
\text { Coefficients }\end{array}$} & \multirow[b]{2}{*}{ Sig. } \\
\hline & & $\mathrm{B}$ & Std. Error & Beta & $\mathrm{t}$ & \\
\hline \multirow[t]{3}{*}{1} & (Constant) & 94,257 & 11,601 & & 8,125 &, 000 \\
\hline & Social Support & ,199 & ,085 & ,221 & 2,341 & ,021 \\
\hline & Self-Regulated Learning &,- 248 & ,120 &,- 195 & $-2,059$ & ,042 \\
\hline
\end{tabular}

a. Dependent Variable: Motivation to learn 
Table 8

Model summary

\begin{tabular}{|c|c|c|c|c|c|c|c|c|c|}
\hline \multirow[b]{2}{*}{ Model } & \multirow[b]{2}{*}{$\mathrm{R}$} & \multirow[b]{2}{*}{ R Square } & \multicolumn{7}{|c|}{ Change Statistics } \\
\hline & & & $\begin{array}{l}\text { Adjusted } \\
\text { Square }\end{array}$ & $\begin{array}{l}\text { R Std. Error of } \\
\text { the Estimate }\end{array}$ & $\begin{array}{l}\text { R Square } \\
\text { Change }\end{array}$ & F Change & df1 & df 2 & $\begin{array}{l}\text { Sig. F } \\
\text { Change }\end{array}$ \\
\hline 1 &, $297 a$ & 088 &, 070 & 5,54224 & ,088 & 4,943 & 2 & 102 &, 009 \\
\hline
\end{tabular}

1. the direct effect of social support $\left(\mathrm{X}_{1}\right)$ on learning motivation $(\mathrm{Y})$

Based on the coefficients table above, it is known that the direct influence of social support variables on learning motivation is a significance value of $0.021<0.05$, it can be concluded that $\mathrm{H}_{1}$ is accepted, which means there is a significant influence of social support (X1) on LM (Y ) with an unstandardized coefficient (B) of 0.199, positive direction means that if social support is increased by 1 , then LM will increase by 0.199 .

2. The direct influence of SRL $\left(\mathrm{X}_{2}\right)$ on LM (Y)

Based on the coefficients table above (see table 10), it is known that the direct influence of the SRL $\left(\mathrm{X}_{2}\right)$ on the LM with the significance value of $0.042<0.05$, it can be concluded that $\mathrm{H}_{2}$ is accepted, which means that there is a significant influence of SRL $\left(\mathrm{X}_{2}\right)$ on LM (Y) with unstandardized coefficients $(\mathrm{B})$ of -0.248 , negative direction means that if SRL is increased by $1, \mathrm{LM}$ will decrease by 0.248 .

3. The simultaneous influence of social support (X1) and SRL (X2) on LM (Y)

Based on the model summary table above (see table 11), it is known that the direct influence of social support (X1) and SRL (X2) simultaneously happens on LM. The value of sig. F change $0.009<0.05$, so it can be concluded that $\mathrm{H} 3$ is accepted which means there is an influence of social support (X1) and SRL (X2) on LM with an R Square value of 0.088 .

This shows that the contribution of the influence of social support and SRL on LM of $8.8 \%$ means there are still $91.2 \%$ which are influenced by other variables. Meanwhile, the value of $\varepsilon 1$ is sought by using the formula $\varepsilon 1=\sqrt{ }(1-0.088)=43.727$. Thus the structural model I path diagram is obtained as follows: 


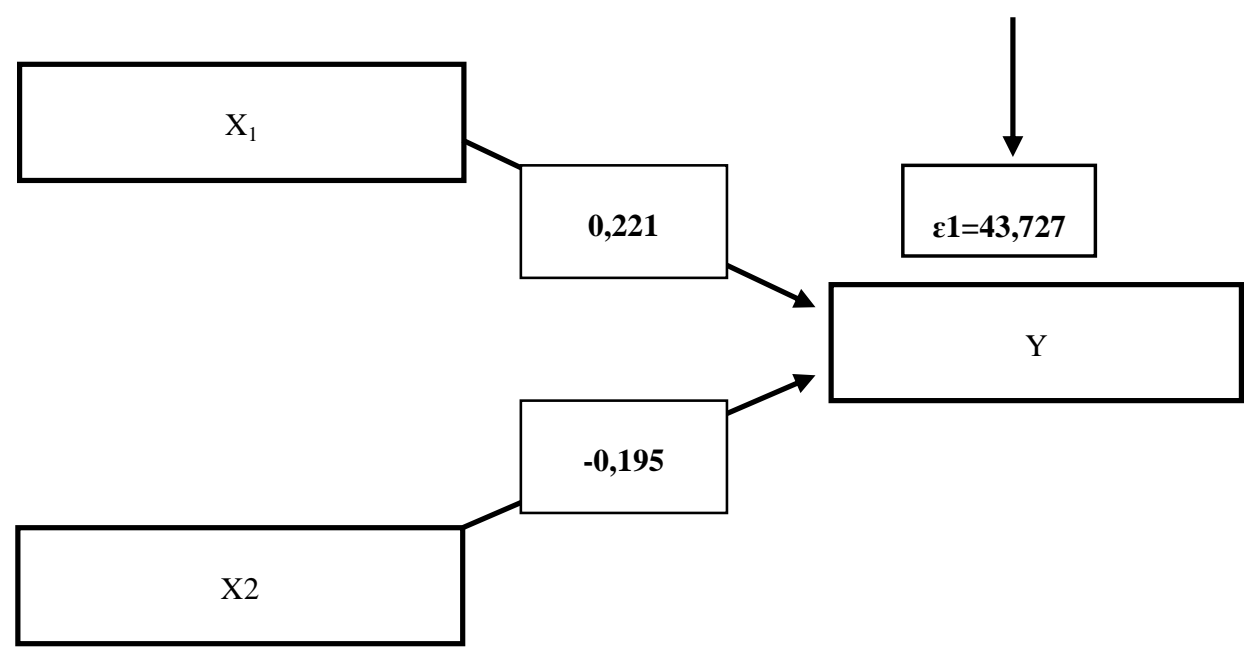

Figure 3

The structural model I path diagram

b. Path analysis test.

Table 9

Coefficients

\begin{tabular}{|c|c|c|c|c|c|c|}
\hline \multirow[t]{2}{*}{ Model } & \multicolumn{3}{|c|}{ Unstandardized Coefficients } & $\begin{array}{l}\text { Standardized } \\
\text { Coefficients }\end{array}$ & \multirow[b]{2}{*}{$\mathrm{T}$} & \multirow[b]{2}{*}{ Sig. } \\
\hline & & $\mathrm{B}$ & Std. Error & Beta & & \\
\hline \multirow{4}{*}{$\begin{array}{l}\text { S } \\
\text { S } \\
\text { I }\end{array}$} & (Constant) & 75,384 & 10,568 & & 7,133 &, 000 \\
\hline & Social Support &,- 038 & ,062 &,- 061 &,- 621 & ,536 \\
\hline & Self-Regulated Learning & 225 & 087 & ,253 & 2,577 & ,011 \\
\hline & Learning Motivaton & ,023 & 070 & ,033 & ,326 &, 745 \\
\hline
\end{tabular}

Table 10

Model summary

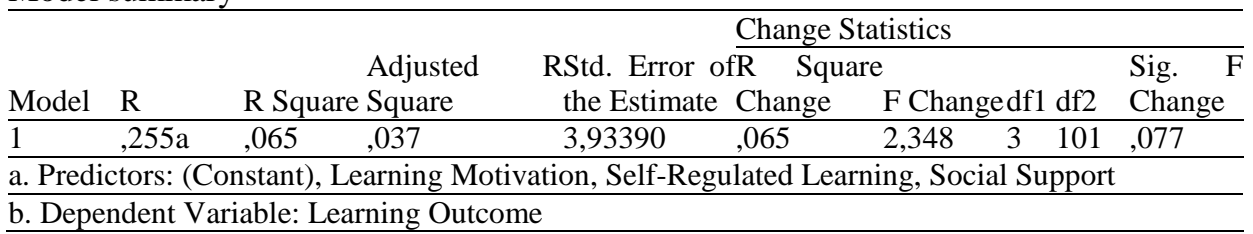

4. The direct influence of social support (X1) on learning outcomes (Z)

Based on the coefficients table above, it is known that the direct influence of social support (X1) on LO is in a significance value of $0.536>0.05$, it can be concluded that $\mathrm{H} 4$ is rejected, which means there is no significant influence of social support on LO 
with an unstandardized coefficient (B) of -0.038 , the direction is negative meaning that if social support is increased by 1 , the $\mathrm{LO}$ will decrease by 0.038 .

5. The direct influence of SRL (X2) on the LO (Z).

Based on the coefficients table above (see table 12), it is known that the direct influence of the variables of SRL on LO is a significance value of $0.011<0.05$. It can be concluded that $\mathrm{H} 5$ is accepted, which means that there is a significant influence of SRL on $\mathrm{LO}$ with unstandardized coefficients (B) of 0.225 , positive direction means that if SRL is increased by 1 , then LO will increase by 0.225 .

6 . The direct influence of learning motivation on learning outcome.

Based on the coefficients table above (see table 12), it is known that the direct influence of LM the LO of the significance value is $0.745>0.05$. It can be concluded that H6 is rejected, which means that there is no significant influence of LM on LO with unstandardized coefficients (B) of 0.023 , positive direction means that if the LM is increased by 1 , then learning LO will increase by 0.023 .

7. The simultaneous influence of social support (X1), self-regulated learning, and learning motivation on learning outcomes.

Based on the model summary table above (see table 13), it is known that the direct effect between social support (X1), SRL, and LM simultaneously come on LO sig. F change $0.077>0.05$, so it can be concluded that $\mathrm{H} 7$ is rejected which means that there is no simultaneous influence of social support (X1), SRL, and LM on LO with grades R Square of 0.065 . This shows that the contribution of social support, SRL, and LM to LO $6.5 \%$ means that there are still $93.5 \%$ influenced by other variables. Meanwhile, the value of $\varepsilon 2$ is sought by using the formula $\varepsilon 2=\sqrt{ }(1-0.077)=30.381$. Thus the structural model II path diagram is obtained as follow:

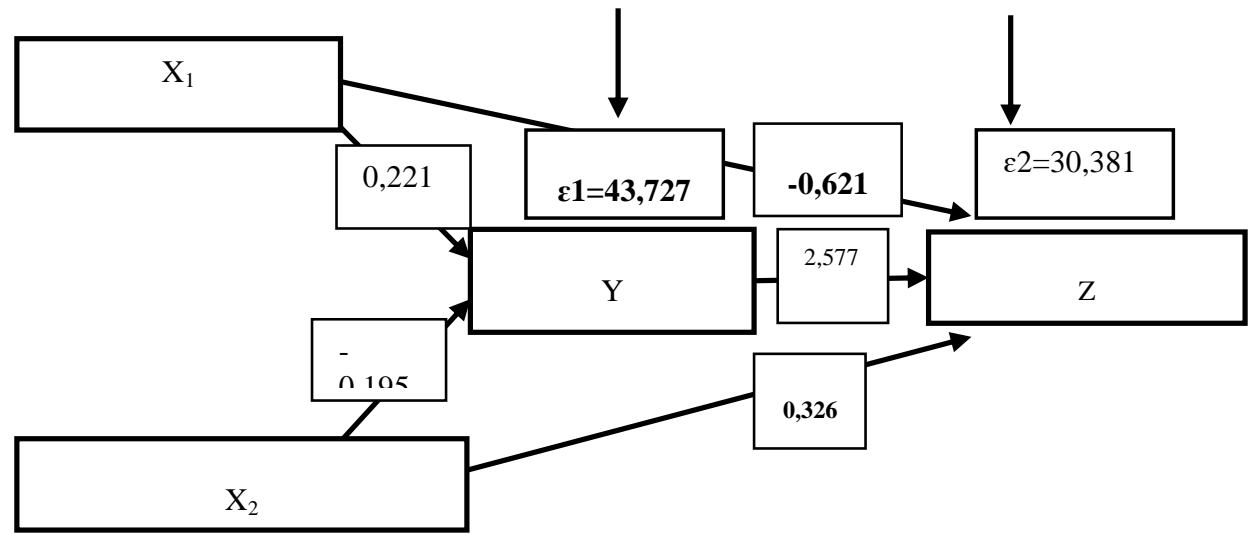

Figure 4

Structural model II path analysis diagram 
8. The indirect influence of social support (X1) on learning outcomes through learning motivation variables.

The direct influence of social support (X1) on LM is $-0,621$. While the indirect influence of social support (X1) on LO through learning motivation is a multiplication of the Beta value of social support (X1) with LM (Y) on LO (Z) namely: 0.221 x 2.577 $=0.569$. Then the total influence of social support $(\mathrm{X} 1)$ on LO $(\mathrm{Z})$ is a direct influence coupled with an indirect influence, namely: $-0,621+0.569=-0,052$. Based on the above calculation, it is known that the value of direct influence is $-0,621$ and the indirect effect is 0.569 which means that the value of the indirect influence is greater than the value of the direct influence. It can be concluded that there is a significant influence of social support on LO through LM.

9. The indirect influence of the self-regulated learning variable (X2) on learning outcomes $(\mathrm{Z})$ through learning motivation variables $(\mathrm{Y})$.

The direct influence of SRL(X2) on LM (Z) is 0.326. While the indirect influence of SRL (X2) on LO (Z) through LM (Y) is the multiplication of the value of Beta SRL (X2) on LO (Y) with LM (Y) namely: $-0,195 \times 2,577=-0,503$. Then the total influence of SRL on LO is the direct influence coupled with the indirect influence, namely: 0.326 $+(-0.503)=-0.177$. Based on the above calculation it is known that the value of the direct influence is 0.326 and the indirect influence is -0.503 . It means that the value of the indirect influence is smaller than the value of the direct influence. This means that $\mathrm{H} 3$ is rejected, so it can be concluded that there is no significant influence of selfregulated learning on learning outcomes through learning motivation.

\section{DISCUSSION}

Learning is designed to students learn, meaning that students are placed as learning subjects. In other words, learning is more oriented towards student activities to obtain learning outcomes in the form of a proportionate combination of cognitive, affective, and psychomotor aspects. In practice, learning outcomes are influenced by various factors both from within and from outside the students. One of the external factors that affect student learning outcomes is social support, in the form of support from parents, teachers, friends and the surrounding community (Tezci, E, et. All, 2015 Siah, PC, 2017; Jie Li, at. all., 2018; Sivandani, A, Koohbanani, EK, Vahidi, T, 2013). The results of this study confirm that there is a significant relationship between social support and learning outcomes.

In line with this research, Rahmatullah (2012) emphasized that there is a positive and significant relationship between social support and student achievement in the subject of Aqidah Akhlak at Madrasah Tsanawiyah Nurul Rahmat Bontolanra, Galesong Utara District, Takalar Regency. Students`social support at MTs. Nurul Rahmat Bontolanra, Galesong Utara District is highly regarded. Likewise, the students' learning achievement in the Akidah Akhlak subject at MTs. Nurul Rahmat Bontolanta, Galesong Utara District, Takalar Regency is in the high category. 
Suciani (2014) also conducted research about the relationship between social support and learning motivation for Esa Unggul University students. From the results of his research, it was also revealed that there was a positive and significant relationship between social support and learning motivation. This means that the more positive the social support students get, the higher the students is motivated to learn . Conversely, the more negative social support students get, the lower the students is motivated to learn.

Furthermore, the factors that influence learning outcomes are aspects of student learning strategies. One of the learning strategies is self-regulated learning, which is defined as a form of individual learning, which autonomously aims to develop measurements (cognition, metacognition, and behavior), and to monitor learning progress. The results of this study confirm that there is a relationship between self-regulated learning and learning outcomes. In line with that, Eva Latipah (2010) asserted that the results of her meta-analysis support previous studies on the role of self-regulated learning strategies on academic achievement. Therefore, to achieve high learning achievement, the use of self regulated learning strategies should be considered.

Sucipto (2015) stated that there is a relationship between Self-regulated leaning and parental support for learning outcomes. He emphasized that Self-Regulated Learning has an effect on the economic learning outcomes of students in the economic subjects of Public High Schools in Jombang. Thus, teachers can help and train students to focus their attention in the teaching and learning process, determine time and complete all activities related to learning objectives, direct students' minds not to delay learning, and determine student learning schedules, carry out actions and students so that they can determine the efforts diligently in completing the tasks.

This research also confirms that there is a relationship between motivation and learning outcomes. Motivation to learn is viewed as a mental support that moves and directs students to carry out learning activities. Ulfah, K.R., et.all (2016) stated that there is a relationship between motivation and learning outcomes of the fifth graders of Public Elementary School Melayu 2 Banjarmasin. The results of his research also confirm that the fifth graders of Public Elementary School Melayu 2 have high motivation and learning outcomes. Besides, Puja \& Syarif, W. (2019) stated that 1) student motivation in the Catering Business Management (PUB) course of the Department of PKK UNP was included in the moderate / adequate category 2) student learning outcomes in the Food Business Management (PUB) course ) PKK UNP Study Program is included in the very good category 3) there is a positive and significant relationship between learning motivation and learning outcomes in the Catering Business Management course with a correlation coefficient value of 0.413 , which indicates the strength of the relationship between learning motivation variables and learning outcomes in the moderate category.

\section{CONCLUSION}

Based on the results of research and discussion above, it can be drawn several conclusions including 1) Social support has a positive and significant effect on learning 
motivation. 2) Self-regulated learning has a negative and significant effect on learning motivation. 3) There is a simultaneous influence between social support and selfregulated learning on learning motivation of $8.8 \%$. This means that there are still $91.2 \%$ which are influenced by other variables. 4) Social support has no effect on learning outcomes and it also has negative direction. 5) Self-regulated learning has a positive and significant effect on learning outcomes. 6) Learning motivation does not affect learning outcomes and it has positive direction. 7) There is simultaneous influence of social support, self-regulated learning, and motivation to learn on learning outcomes of $6.5 \%$ means there are still $93.5 \%$ which is influenced by other variables. 8) There is a significant influence of social support on learning outcomes through learning motivation. 9)There is no significant effect of self-regulated learning on learning outcomes through learning motivation.

\section{REFERENCES}

Abadikhah, S. Aliyan, Z. \& Talebi. S.H. (2018). EFL Students' Attitudes Towards SelfRegulated Learning Strategies In Academic Writing, Issues in Educational Research, 28(1), 1-17.

Adams, N. E. (2015). Bloom's Taxonomy Of Cognitive Learning Objective, J Med Libr Assoc, 103(3), 152-153.

Al-Mutawaha, M. A, Thomasa, R \& Khineb, M.S. (2017). Investigation into Selfregulation, Engagement in Learning Mathematics and Science and Achievement among Bahrain Secondary School Students, International Electronic Journal Of Mathematics Education, 12(3), 633-653.

Alsubaie, M.M. H. J. Stain, H.J., Webster, L. A. D. \& Wadman, R(2019). The Role Of Sources Of Social Support On Depression And Quality Of Life For University Student,International Journal of Adolescence and Youth , 24(2), 484-496.

Amirkhanovaa, K.M. Ageevab, A.V,., Rustam M. F., (2016). Enhancing Students' Learning Motivation through Reflective Journal Writing, The European Proceedidng of Social and Behavorial Sciences, IFTE : 2nd International Forum on Teacher Education, 14-17.

Anwari, A. (2019). Factors Contributing Students Motivation Toward English Language Learning, American International Journal of Humanities, Arts and Social Sciences, 1(2), 29-39.

Ati, M.R.S., Matulessy.A., Farid, M. (2018). The Relationship Between Gratitude and Social Support with The Stress of Mother Who Have Children in Special Needs, Journal of Child Development Studie, 3(01), 44-58.

Bakar, R. (2014).The Effect Of Learning Motivation On Student's Productive Competencies In Vocational High School, West Sumatra, International Journal of Asian Social Science, 4(6), 722-732. 
Banarjee, P. \& Kumar, K. (2014).A Study on Self-Regulated Learning and Academic Achievement among the Science Graduate Students, International Journal of Multidisciplinary Approach and Studies, 1(1), 329-342.

Barbosa, V., Leme, R.., Prette,Z.A.P.D., Coimbra.S. (2015). Social Skills, Social Support and Well-Being in Adolescents of Different Family Configurations, Paidéia (Ribeirão Preto) 25(6), 9-17.

Cazan, A.M., (2012). Enhancing Self Regulated Learning By Learning. Journals, Procedia - Social and Behavioral Sciences, 33, 413-417.

Chen. C.S. (2013) Self-regulated Learning Strategies and Achievement in an Introduction to Information Systems Course, Information Technology, Learning, and Performance Journal, 20(1). 405-410.

Fauziah, M., Handarini, M., Muslihati, (2018). Self-esteem, Social Support, Personality and Psychological Well Being of Junior High School Student, Jurnal Pendidikan Humaniora, 6(1).17-23.

Harold F. O’Neila, H. F., Wainessa, R \& Bakerb, E. B., (2005). Classification Of Learning Outcomes: Evidence From The Computer Games Literature, The Curriculum Journal, 16(4), 455-474.

Heather J., Murphy, S.T., \& Valente, T.W. (2014).It's Better to Give Than to Receive: The Role of Social Support, Trust, and Participation on HealthRelated Social Networking Site,” Journal of Health Communication, 19(12), 1424-1439.

Ilyas, (2016). The Relationship Between Self Regulated Learning And Emotional Maturity With Academic Procrastination, Analitika, 8(1), 25-29.

Irawan A , Dede Ruslan, D. ,Mare, A.S. (2019). The Effects of Learning Models of Discovery Learning and Learning Interest on Social Science Learning Outcomes in Grade VII of Junior High School of Al-Azhar Medan, Budapest International Research and Critics in Linguistics and Education (BirLE) Journal, 2(3), 94-105.

Jafarigohar, M, Mortazav, M. (2013). The Effects of Different Types of Reflective Journal Writing on Learners' Self-regulated Learning, Iranian Journal of Applied Linguistics (IJAL), 16(1), 59-78.

Johnson, G. M, \& Davie, S.M., Self-Regulated. (2014).Learning in Digital Environments: Theory, Research, Praxiss, British Journal of Research, 1(2), 068-080

Latipah, E., (2010), Strategi Self Regulated Learning Dan Prestasi Belajar: Kajian Meta Analisis, Jurnal Psikologi, 37(1), 110 - 129.

Marhamah, F, \& Hamzah, H.B. (2016). The Relationship Between Social Support And Academic Stress Among First Year Students At Syiah Kuala University, Jurnal Psikoislamedia,42(1), 14-20.

Marlina, (2017). Increasing Self Regulated Learning Of Students With Special Needs Through The Ilbawel Model, Journal of ICSAR, 1(1), 72-80. 
Montalvo, F. T. \& Torres, C. G. (2004). Self-Regulated Learning: Current and Future Directions, Electronic Journal of Research in Educational Psychology, 2(1), 1-34.

Moos, D. C. \& Ringdal, A. (2012). Review Article Self-Regulated Learning in the Classroom: A Literature Review on the Teacher's Role, Hindawi Publishing Corporation Education Research International, 3, 1-15.

Paris, S, G. \& Paris, A.H., (2003). Classroom Applications of Research on SelfRegulated Learning Self-Regulated Learning, Educational Psychologist, 36(2), 89-101.

Pintrich, P. R (2003). A Motivational Science Perspective on the Role of Student Motivation in Learning and Teaching Contexts, Journal of Educational Psychology, 95(4), 667-689.

Pintrich, P. R. \& De Groot, E.V. (1990). Motivational and Self-Regulated Learning Components of Classroom Academic Performance, Journal of Educational Psychology, 82(1), 33-40

Rahmatullah, (2012) Hubungan Antara Dukungan Sosial Dengan Prestasi Belajar Siswa Dalam Mata Pelajaran Akidah Akhlak Di MTS Nurul Rahmat Bontolanra Kec. Galesong Utara Kabupaten Takalar, Thesis, Fakultas Tarbiyah Dan Keguruan UIN Alauddin Makassar, http://repositori.uin-alauddin.ac.id.

Saad, M.A.E. (2015) The Effectiveness a Self Regulated Learning- Based Training Program on Improving Cognitive and Metacognitive EFL Reading Comprehension of 9th Graders with Reading Disabilities,International Journal of Psycho-Educational Sciences, 4(3), 45-59.

Saks, K. Ä. L. (2014). Distinguishing Self-Directed and Self-Regulated Learning and Measuring them in the E-learning Context, Procedia - Social and Behavioral Sciences, 112, 190-198.

Schneider, F. W., Gruman, J. A., \& Coutts, L. (2005). Understanding And Addressing Social And Practical Problems. Applied Social Psychology USA: Sage Publication.

Setiani, N., Santoso, B., Kurjono.(2018). Self Regulated Learning And Achievement Motivation To Student Academic Procrastination, Manajerial, 3(4), 17-38.

Siah, P. C., Niew, K. M.. Wong, S. F, Jie, S. C.,(2016). The Relationship of Social Support And Motivation With University Adjustment Among Year One To Year Three Tertiary Undergraduates In Malaysia, Journal of Institutional Research In South East Asia, 14(1), 17-28.

Sivandani, A, Koohbanani, E.K., Vahidi, T. (2013). The Relation Between Social Support And Self-Efficacy With Academic Achievement And School Satisfaction Among Female Junior High School Students In Birjand, Procedia - Social And Behavioral Sciences, 84, $668-673$

Suciani, D \& Safitri, (2014).Hubungan Dukungan Sosial Dengan Motivasi Belajar Pada Mahasiswa Universitas Esa Unggul, Jurnal Psikologi, 12( 2), 43-47. 
Sucipto, (2014). Pengaruh Self-Regulated Learning Dan Dukungan Orang Tua Terhadap Hasil Belajar Peserta Didik Pada Mata Pelajaran Ekonomi Program Studi Ips Sma Negeri Di Kota Jombang, Jurnal Ekonomi dan Pendidikan Kewirausahaan, 2(2), 237-251

Sungur, S. \& Tekkaya, C. (2006). Efferct of Problem based Learning and Traditional Instruction on Self Regulated Learning. The Journal of Education Research, Heldrey Publication, 99(5), 307-320.

Tezci1, E., Sezer , F., Urgan, U \& Aktan, S. (2016) A Study On Social Support And Motivation., Anthropologist, 22(2), 284-292.

Ulfah, R., Santoso, A., Utaya, S.,(2016), Hubungan Motivasi Dengan Hasil Belajar IPS, Jurnal Pendidikan: Teori, Penelitian, Dan Pengembangan, 1(8), 1607-1611

Umayyah, U. (2018). Social Support As A Mediator Between Social Identity And College Student's Stress, Psychological Research and Intervention, 1(1), 32-42

Wang, X, Cai, L, Qian, J. \& Peng, J. (2014). Social support moderates stress effects on depression, International Journal of Mental Health Systems, 8(41), 2-5.

Yulianti, P, Sano,.A. (2016). Self Regulated Learning Siswa, Dilihat Dari Hasil Belajar, Indonesian Institute for Counseling, Education and Therapy (IICET), 2(1), 98-102.

Yuliany, N, (2018), Hubungan Antara Motivasi Belajar Dan Hasil Belajar Siswa SDN, Emmy Saelan Makassar, Auladuna: Jurnal Pendidikan Dasar Islam, 5(2), 126-137,

Zimmerman, B J. (1989) A Social Cognitive View of Self-Regulated Academic Learning, Journal of Educational Psychology, 81(3), 329-339. 